\title{
LOW BONE MINERAL DENSITY IN BRAZILIAN PATIENTS AT DIAGNOSIS OF CELIAC DISEASE
}

\author{
Joyce Timmermans Pires da SILVA', Renato M NISIHARA², Luís Roberto KOTZE', \\ Márcia OLANDOSKI ${ }^{1}$ and Lorete Maria da Silva KOTZE'
}

Received 23/1/2015

Accepted 25/2/2015

\begin{abstract}
Background - Low bone mineral density is considered an extra-intestinal manifestation of celiac disease with reduced bone mass, increased bone fragility, and risk of fractures. Celiac disease is considered a condition at high risk for secondary osteoporosis and the evaluation of bone density is very important in the clinical management of these patients. Objective - The present study aimed to investigate bone alterations in celiac patients from Curitiba, South Region of Brazil at diagnosis, correlating the findings with age and gender. Methods - Patients who were included in the study were attended to in a private office of the same physician from January 2009 to December 2013. The diagnosis of celiac disease was done through clinical, serological and histological findings. All data were collected from the medical charts of the patients. After the diagnosis of celiac disease, evaluation for low bone mineral density was requested by dual-energy X-ray absorptiometry (DEXA). DEXA bone densitometer was used to estimate low bone mineral density at the lumbar spine and femur. Results - A total of 101 patients, $82(81.2 \%)$ female and $19(18.8 \%)$ male subjects, with mean age of 39.0 \pm 3.03 years were included. At celiac disease diagnosis, $36(35.6 \%)$ were younger than 30 years, $41(40.6 \%)$ were between 31 and 50 years, and $24(23.8 \%)$ were older than 50 years. Among the evaluated patients, $69(68.3 \%)$ presented low bone mineral density, being $47 \%$ with osteopenia and $32 \%$ with osteoporosis. Patients who were older than 51 years and diagnosed with celiac disease presented low bone mineral density in $83.3 \%$ (20/24) of the cases. As expected, age influenced significantly the low bone mineral density findings. Among women, low bone mineral density was present with high frequency (60\%) from 30 to 50 years. In patients diagnosed older than 60 years $(n=8)$, all the women $(n=5)$ and two of the three men had osteoporosis. Conclusion - This study demonstrated that $69 \%$ of Brazilian patients with celiac disease at diagnosis had low bone mineral density, being more frequent in women older than 50 years.
\end{abstract}

HEADINGS - Celiac disease. Osteoporosis. Metabolic bone diseases. Densitometry

\section{INTRODUCTION}

The clinical picture of celiac disease (CD) is highly variable, in which the immune response is mainly targeted to the intestinal mucosa; however, it can affect any organ or tissue. Low bone mineral density (BMD) is considered an extra-intestinal manifestation of CD with reduced bone mass, increased bone fragility, and risk of fractures ${ }^{(6)}$. CD is considered a condition at high risk for secondary osteoporosis, and the evaluation of bone density is very important in the clinical management of these patients. Nevertheless, studies investigating the prevalence of bone derangement in patients with CD are still inconclusive because both old and recent findings are widely incongruous ${ }^{(4)}$.
Intestinal malabsorption and inflammation contribute to the pathophysiology of bone damage in CD. Villous atrophy is responsible for alterations of intestinal absorption, and a negative calcium balance was shown in CD patients because of several mechanisms: malabsorption of calcium in untreated patients ${ }^{(9)}$, partially reversible after gluten-free diet $(\mathrm{GFD})^{(12)}$; the reduction of calcium intake ${ }^{(5)}$ also because of a secondary lactose intolerance; and the reduction of intestinal calcium absorption because of its binding to intraluminal unabsorbed fatty acids ${ }^{(9)}$. Also, vitamin $\mathrm{D}$ deficiency is known to be common among patients with $\mathrm{CD}$, although there are no changes in the expression of vitamin D receptors ${ }^{(1)}$. Because of the increased prevalence of osteoporosis, celiac patients

Declared conflict of interest of all authors: none

Disclosure of funding: no funding received

${ }^{1}$ Serviço de Gastroenterologia, Hospital Cajuru, Pontifícia Universidade Católica do Paraná, Curitiba, PR: ${ }^{2}$ Departamento de Medicina, Universidade Positivo, Curitiba, PR, Brasil.

Correspondence: Renato M. Nisihara. Rua Prof. Pedro Viriato, 5300 - CEP 81280-330 - Curitiba, PR, Brasil. E-mail: renatonisihara@gmail.com 
have a high risk of fracture, estimated between 3.5 and 7 times higher than that of the unaffected population of the same age and gender ${ }^{(14)}$.

The present study aimed to investigate bone alterations in celiac patients from Curitiba, South Region of Brazil at diagnosis, correlating the findings with age and gender.

\section{METHODS}

This study was approved by the local Ethics in Research Committee (Pontifical Catholic University). Patients who were included in the study were attended to in a private office of the same physician from January 2009 to December 2013. The diagnosis of $\mathrm{CD}$ was done through clinical, serological (IgA antiendomysium), and histological findings (Marsh classification) according to World Gastroenterology Organization $^{(16)}$. All data were collected from the medical charts of the patients. After the diagnosis of $\mathrm{CD}$, evaluation for BMD was requested by dual-energy X-ray absorptiometry (DEXA). DEXA bone densitometer was used to estimate $\mathrm{BMD}$ at the lumbar spine and femur. An X-ray tube and detector scanned over the area of interest and generated an image of bone mineral content expressed in grams of calcium. Built-in software identified the projected bone area using an edge detection algorithm. Dividing bone mineral content by bone area gave the BMD. This value was compared with that of BMD of young population, and the result was expressed as T score. WHO criteria were used to define BMD as normal ( $\mathrm{T}$ score, $>-1$ ), osteopenia ( $\mathrm{T}$ score, -1 to -2.5 ), osteoporosis (T score, $<-2.5$ ), and severe osteoporosis (fragility fractures; T score, $<-2.5)^{(15)}$.

Frequency data were analyzed in percentages. Values were expressed in mean and standard deviation. Comparison of nominal data was done using analysis of variance and Fisher test. Significance adopted was of 5\%. Statistical tests were calculated with the help of the software Graph Pad Prism 5.0.

\section{RESULTS}

A total of 101 patients, $82(81.2 \%)$ female and $19(18.8 \%)$ male subjects, with mean age of $39.0 \pm 3.03$ years were included in the investigation. At CD diagnosis, $36(35.6 \%)$ were younger than 30 years, $41(40.6 \%)$ were between 31 and 50 years, and $24(23.8 \%)$ were older than 50 years.

BMD evaluated by DEXA in femur and spinal cord was demonstrated in Table 1 and Figure 1. Among the evaluated patients, $69(68.3 \%)$ presented low BMD, being 47\% with osteopenia and $32 \%$ with osteoporosis. Bone alterations were observed in the young group, wherein three patients were younger than 30 years; one of them was a 19-year-old male patient, presented osteoporosis. Patients who were older than 51 years and diagnosed with celiac disease presented low BMD in $83.3 \%(20 / 24)$ of the cases. As expected, age influenced significantly the BMD findings.

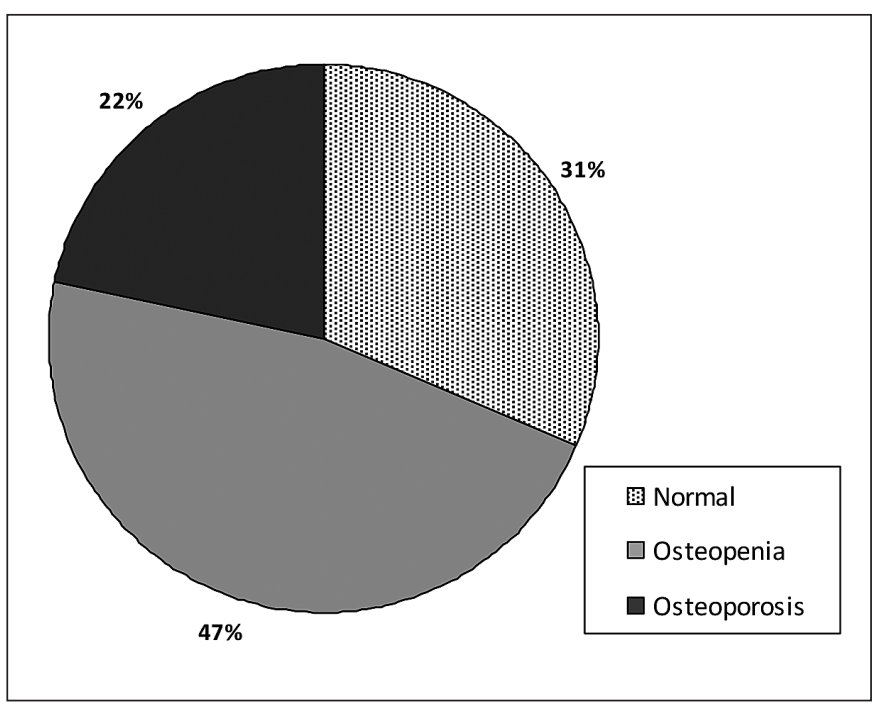

FIGURE 1. Bone alterations in celiac patients at diagnosis $(\mathrm{n}=101)$.

TABLE 1. DEXA results in the studied patients

\begin{tabular}{|c|c|c|c|c|c|}
\hline Local & Result & \multicolumn{3}{|c|}{ Age (years) } & $P$ value * \\
\hline \multirow[b]{2}{*}{ FEMUR } & Normal & $12(33.3 \%)$ & $19(46.3 \%)$ & $4(16.7 \%)$ & \multirow[b]{2}{*}{0.005} \\
\hline & Osteopenia & $22(61.1 \%)$ & $14(34.1 \%)$ & $11(45.8 \%)$ & \\
\hline \multirow{2}{*}{$\begin{array}{l}\text { SPINAL } \\
\text { CORD }\end{array}$} & Normal & $16(44.4 \%)$ & $14(34.1 \%)$ & $4(16.7 \%)$ & \multirow[b]{2}{*}{0.003} \\
\hline & Osteopenia & $17(47.2 \%)$ & $20(48.8 \%)$ & $8(33.3 \%)$ & \\
\hline
\end{tabular}

* Chi square test 
Table 2 shows the results of DEXA according to gender. Among women, BMD was present with high frequency $(60 \%)$ from 30 to 50 years. In patients diagnosed older than 60 years $(n=8)$, all the women $(n=5)$ and 2 of the 3 men had osteoporosis. Two women (51 and 53 years) with previous diagnosis of $\mathrm{CD}$ had fracture history.

\section{DISCUSSION}

This study evaluated and showed high prevalence of low BMD in Brazilian patients with CD at diagnosis. Also, osteopenia and osteoporosis were found at an early age in celiac patients at diagnosis.

Recently, Gusso et al. ${ }^{(3)}$ studied 100 consecutive male and female patients with osteoporosis (convenience sample) who were treated in a single tertiary center at South Brazil. Only one patient was diagnosed with $\mathrm{CD}$ and referred minor gastrointestinal complaints. The authors found low rate of patients with $\mathrm{CD}$ in this group. On the other hand, the present study found that $69 \%$ of the CD patients at diagnosis had low BMD, showing that this is a frequent finding in $\mathrm{CD}$ regardless of the clinical presentation. The prevalence of low BMD in untreated celiac disease is reported to be $38 \%$ to $72 \%$ in different populations ${ }^{(8)}$. Among them, the prevalence of osteoporosis is at least twice that of the unaffected population in the same age range ${ }^{(13)}$.

Bone alterations were thought to result in intestinal malabsorption and steatorrhea; however, currently, a more complex interaction between cytokines and local/systemic factors influencing bone formation and reabsorption is envisaged ${ }^{(7)}$. Osteotropic cytokines are involved in bone remodeling because they regulate the differentiation and activation of costeoblasts and osteoclasts. In inflammatory diseases, including $\mathrm{CD}$, the chronic release of proinflammatory cytokines is well known. Pathogenesis of bone derangement in patients with $\mathrm{CD}$ need to be clearly established, and other mechanisms should be investigated. Other research has demonstrated the association between a genetic predisposition (IL-1 gene) and low bone mass in patients with $\mathrm{CD}^{(10)}$. Additionally, calcium supply in the diet of patients with CD is reduced even more because of a decreased intake of milk and dairy products in an effort to avoid lactose. Secondary lactose intolerance resulting from decreased lactase production by the damaged villi is common in patients with $\mathrm{CD}^{(5)}$.
Low BMD is described in both asymptomatic and symptomatic CD patients. Worrying is the situation of patients with asymptomatic or silent $C D$ because anemia and vitamin $\mathrm{D}$ alterations show a very high prevalence also in this subgroup $^{(2)}$. Considering the prevalence of bone loss in patients with and without overt malabsorption symptoms, BMD measurement could provide more important information in asymptomatic than in clinically overt malabsorber patients. Moreover, the most important risk factor at diagnosis seems to be the age of the patient. Olmos et al. ${ }^{(11)}$, in a meta-analysis about fracture risk, which included 21,000 celiac patients and about 100,000 controls, confirmed a $43 \%$ increase in the prevalence of fractures among celiac ( $8.7 \%$ vs. $6.1 \%)$. In our study, two patients attended had fracture history and previous $\mathrm{CD}$ diagnosis.

In general population, low BMD was associated with gender, being more prevalent in female subjects. The same occurred in $\mathrm{CD}$; however, as demonstrated in the present study, osteopenia and osteoporosis can appear early in younger male subjects. In celiac patients diagnosed after 50 years old, both women and men presented low BMD. Bone disease is known to be a multifactorial illness, and other factors, such as hormones, smoking, and physical activity, also have great influence.

A strict gluten-free diet is thought to be the only effective treatment for $\mathrm{CD}$; however, currently, a question of whether GFD alone is an effective treatment to correct bone alterations in patients with $\mathrm{CD}$ is under debate ${ }^{(7)}$.

Concluding, this study demonstrated that $69 \%$ of Brazilian patients with $\mathrm{CD}$ at diagnosis had bone alterations in all ages, mainly osteopenia. The authors recommend bone evaluation in all patients diagnosed with $\mathrm{CD}$, aiming precocious detection and treatment of these diseases.

\section{Authors' contributions}

Silva JTP and Kotze LR: study design, data collection, analysis and interpretation of data, approval of final version of the manuscript. Olandoski M: analysis and/or interpretation of data, statistical analysis, final approval of manuscript conception. Nisihara RM and Kotze LMS: conception and study design, analysis and/or interpretation of data, final approval of manuscript, writing of the manuscript or review of its content.

TABLE 2. DEXA results in celiac patients at diagnosis in according to age

\begin{tabular}{|c|c|c|c|c|c|c|}
\hline & \multicolumn{2}{|c|}{ Normal (\%) } & \multicolumn{2}{|c|}{ Osteopenia (\%) } & \multicolumn{2}{|c|}{ Osteoporosis (\%) } \\
\hline & Male & Female & Male & Female & Male & Female \\
\hline$<30$ years $(\mathrm{n}=36)$ & 50 & 20.8 & 41.5 & 75 & 8.5 & 4.2 \\
\hline 30 to 50 y $(n=41)$ & 100 & 42 & 0 & 36.8 & 0 & 21.2 \\
\hline
\end{tabular}


Silva JTP, Nisihara RM, Kotze LR, Olandoski M, Kotze LMS. Alterações ósseas em celíacos brasileiros ao diagnóstico. Arq Gastroenterol. 2015,52(3):176-9.

RESUMO - Contexto - Baixa densidade mineral óssea é considerada uma manifestação extra-intestinal da doença celíaca com redução da massa óssea, aumento da fragilidade óssea e risco de fraturas. A doença celíaca é considerada uma condição de alto risco para a osteoporose secundária e a avaliação da densidade óssea é muito importante no manejo clínico dos pacientes. Objetivo - O presente estudo teve como objetivo investigar as alterações ósseas presentes em pacientes com doença celíaca de Curitiba-PR, no momento do diagnóstico, correlacionando os achados com a idade e gênero. Métodos - Os pacientes incluídos no estudo foram atendidos por um só médico no período de janeiro/2009 a dezembro/2013. O diagnóstico da doença celíaca foi feito através das manifestações clínicas, sorologia específica e achados histológicos da mucosa duodenal. Todos os dados foram coletados a partir dos prontuários dos pacientes. Após o diagnóstico da doença celíaca, foi solicitada a avaliação de densidade mineral óssea por meio de densitometria (dual-energy X-ray absorptiometry - DEXA). DEXA foi utilizada para estimar a densidade mineral óssea na coluna lombar e fêmur. Resultados - Um total de 101 pacientes, $82(81,2 \%)$ mulheres e $19(18,8 \%)$ homens, com idade média de 39,0 $\pm 3,03$ anos foram incluídos. No momento do diagnóstico de doença celíaca, $36(35,6 \%)$ tinham menos de 30 anos, 41 (40,6\%) tinham entre 31 e 50 anos, e 24 (23,8\%) tinham mais de 50 anos. Entre os pacientes avaliados, $69(68,3 \%)$ apresentaram baixa densidade mineral óssea, 47\% deles com osteopenia e 32\% com a osteoporose. Os pacientes maiores de 51 anos de idade apresentaram baixa densidade mineral óssea em 83,3\% (20/24) dos casos. Como esperado, a idade influenciou significativamente os resultados da baixa densidade mineral óssea. Entre as mulheres, baixa densidade mineral óssea foi observada com alta frequência (60\%) também na faixa etária entre 30 a 50 anos. Pacientes diagnosticados mais de 60 anos ( $\mathrm{n}=8)$, todas as mulheres ( $\mathrm{n}=5)$ e dois dos três homens tinham osteoporose. Conclusão - O presente estudo demonstrou que $69 \%$ dos pacientes brasileiros com doença celíaca no momento do diagnóstico apresentaram baixa densidade mineral óssea, sendo mais frequente em mulheres com mais de 50 anos.

DESCRITORES - Doença celíaca. Osteoporose. Doenças ósseas metabólicas. Densitometria.

\section{REFERENCES}

1. Colston KW, Mackay AG, Finlayson C, Wu JC, Maxwell JD. Localization of vitamin D receptor in normal human duodenum and in patients with coeliac disease. Gut. 1994;9:1219-25.

2. Di Stefano M, Mengoli C, Bergonzi M, Corazza GR. Bone mass and mineral metabolism alterations in adult celiac disease: pathophysiology and clinical approach. Nutrients. 2013;22;5(11):4786-99.

3. Gusso L, Simões MC, Skare TL, Nisihara R, Burkiewicz CC, Utiyama S. Celiac disease screening in Brazilian patients with osteoporosis. Arq Bras Endocrinol Metabol. 2014;58(3):270-3.

4. Heikkilä K, Pearce J, Mäki M, Kaukinen K. Coeliac disease and bone fractures: a systematic review and meta-analysis. J Clin Endocrinol Metab. 2014:jc20141858.

5. Kinsey L, Burden ST, Bannermann E. A dietary survey to determine if patients with celiac disease are meeting current healthy eating guidelines and how their diet compares to that of the british general population. Eur. J. Clin. Nutr. 2008;62(11):1333-42.

6. Kotze LMS, Utiyama SRR. Doença celíaca e outros distúrbios na absorção de nutrientes. In: Dani R, Passos MCF. Gastroenterologia Essencial, $4^{\mathrm{a}}$.Ed, Guanabara-Koogan, Rio de Janeiro, 2011 pp 294-330.

7. Krupa-Kozak U. Pathologic bone alterations in celiac disease: etiology, epidemiology, and treatment. Nutrition. 2014;30:16-24.

8. Larussa T, Suraci E, Nazionale I, et al. Bone mineralization in celiac disease. Gastroenterol Res Pract. 2012;2012;198025.
9. Molteni N, Bardella MT, Vezzoli G, Pozzoli E, Bianchi P. Intestinal calcium absorption as shown by stable strontium test in celiac disease before and after gluten-free diet. Am. J. Gastroenterol. 1995,90(11):2025-28.

10. Moreno ML, Crusius JB, Cherñavsky A, Sugai E, Sambuelli A, Vazquez H, et al. The IL-1 gene family and bone involvement in celiac disease. Immunogenetics. 2005;57(8):618-20.

11. Olmos M, Antelo M, Vazquez H, Smecuol E, Maurino E, Bai JC. Systematic review and meta-analysis of observational studies on the prevalence of fractures in coeliac disease. Dig Liver Dis. 2008;40(1):46-53.

12. Pazianas M, Butcher GP, Subhani JM, Finch PJ, Ang L, Collins C, et al. Calcium absorption and bone mineral density in celiacs after long term treatment with gluten-free diet and adequate calcium intake. Osteoporos. Int. 2005,16(1),56-63.

13. Sundar N, Crimmins R, Swift G. Clinical presentation and incidence of complications in patients with coeliac disease diagnosed by relative screening. Postgrad Med J 2007:83(978):273-6.

14. Walters JR, Banks LM, Butcher GP, Fowler CR. Detection of low bone mineral density by dual energy $\mathrm{X}$ ray absorptiometry in unsuspected suboptimally treated coeliac disease. Gut 1995;37(2):220-4.

15. World Health Organization. Assessment of fracture risk and its application to screening for postmenopausal osteoporosis. World Health Organ Tech Rep Ser. 1994:843:1-129.

16. World Gastroenterology Organization. Practice guidelines: Doença celíaca. 2005. [Access 2013 July 10]. Available from: http://www.worldgastroenterology.org/ assets/downloads/pt/pdf/guidelines/celiac_disease_pt.pdf>. 